\title{
Selective Inner Hair Cell Loss in Prematurity: A Temporal Bone Study of Infants from a Neonatal Intensive Care Unit
}

\author{
Monica Amatuzzi $^{1}$, M. Charles Liberman ${ }^{2,3}$, and Clarinda Northrop ${ }^{3,4}$ \\ ${ }^{1}$ Department of Otorhinolaryngology, Universidade de São Paulo, São Paulo, Brazil \\ ${ }^{2}$ Department of Otology and Laryngology, Harvard Medical School, Boston, MA, USA \\ ${ }^{3}$ Eaton-Peabody Laboratory, Massachusetts Eye E E Ear Infirmary, 243 Charles St., Boston, MA 02114-3096, USA \\ ${ }^{4}$ Temporal Bone Foundation, Boston, MA, USA
}

Received: 16 March 2011; Accepted: 10 May 2011; Online publication: 14 June 2011

\begin{abstract}
Premature birth is a well-known risk factor for sensorineural hearing loss in general and auditory neuropathy in particular. However, relatively little is known about the underlying causes, in part because there are so few relevant histopathological studies. Here, we report on the analysis of hair cell loss patterns in 54 temporal bones from premature infants and a control group of 46 bones from full-term infants, all of whom spent time in the neonatal intensive care unit at the Hospital de Niños in San Jose, Costa Rica, between 1977 and 1993. The prevalence of significant hair cell loss was higher in the preterm group than the full-term group ( $41 \%$ vs. $28 \%$, respectively). The most striking finding was the frequency of selective inner hair cell loss, an extremely rare histopathological pattern, in the preterm vs. the full-term babies ( $27 \%$ vs. $3 \%$, respectively). The findings suggest that a common cause of non-genetic auditory neuropathy is selective loss of inner hair cells rather than primary damage to the cochlear nerve.
\end{abstract}

Keywords: auditory neuropathy, deafness, cochlea, histopathology

Correspondence to: M. Charles Liberman · Eaton-Peabody Laboratory, Massachusetts Eye \& Ear Infirmary - 243 Charles St., Boston, MA 02114-3096, USA. Telephone: +1-617-573-3745; fax: +1-617-720-4408; email: charles_liberman@meei.harvard.edu

\section{INTRODUCTION}

Infants from the neonatal intensive care unit (NICU) are at increased risk for sensorineural hearing loss. Estimates suggest that as many as $1.5 \%$ of NICU survivors have a significant hearing loss compared with only $0.3 \%$ of those without such serious neonatal health issues (Xoinis et al. 2007). Prevalence increases to $3 \%$ if the sample is limited to premature infants born $<28$ weeks' gestation (Robertson et al. 2009). Many risk factors have been suggested, including low birth weight, respiratory distress, hyperbilirubinemia, acoustic injury, and ototoxic drugs (Cristobal and Oghalai 2008; Teagle et al. 2010). However, little is known about the underlying cochlear histopathology because biopsy of the human inner ear is impossible, and there are relatively few descriptions of temporal bone histopathology in neonatal ears (Slack et al. 1986; Amatuzzi et al. 2001).

The development of objective and minimally invasive tests of cochlear function based on measurements of auditory brainstem responses (ABRs) and otoacoustic emissions (OAEs) has enabled a degree of differential diagnosis of the causes of sensorineural hearing loss in human patients. Comparison of results from these two tests has revealed that a subset of sensorineural hearing impairments arise despite apparently normal function of the outer hair cells, as implied by intact OAE responses despite absent or greatly attenuated ABRs. This clinical condition has been termed auditory neuropathy (AN; Starr et al. 1996, 2000), even though it could logically arise from either damage/degeneration of the cochlear nerve or 
selective damage/degeneration of the inner hair cells, which provide the exclusive synaptic drive to $95 \%$ of the cochlear nerve fibers (Spoendlin 1972). Depending on the size and nature of the population sampled, estimates of the prevalence of AN range anywhere from 5\% to $15 \%$ of those with sensorineural hearing loss (Rance et al. 1999; D'Agostino and Austin 2004).

In a prior study of temporal bones from 15 NICU patients, selective inner hair cell loss was seen in three cases. The finding was surprising since selective inner hair cell loss is an uncommon pathology in both the human and animal literature. The finding was also intriguing because all three cases were preterm babies and because there are many reports in the literature of an association between AN and prematurity (Rance et al. 1999; Madden et al. 2002; Beutner et al. 2007; Xoinis et al. 2007).

To better understand the frequency of selective inner hair cell loss in infants and its relation to premature birth, we studied 100 temporal bones, collected from the NICU at the Hospital de Niños in San Jose, Costa Rica, between 1977 and 1993. The sample included the temporal bones from seven premature infants studied previously (Amatuzzi et al. 2001), plus an additional 20, for a total of 27 cases (54 ears) with $\leq 36$ weeks' gestation. For controls, we considered eight full-term cases from the previous study and added 15 new ones, for a total of 46 full-term ears. The two samples were matched with respect to age at death.

\section{METHODS}

\section{Temporal bone sample}

We studied temporal bones of all the preterm neonates from the Temporal Bone Foundation Collection, i.e., 27 cases (54 ears) consisting of 17 male and 10 female patients, born after 26-36 weeks' gestation. The age at time of death varied from 1 day to 6 months, and the birth weight ranged from $800 \mathrm{~g}$ to $2800 \mathrm{~g}$ (See Table 1). The control group included 23 full-term neonates ( 46 ears) who also spent time in the same neonatal intensive care unit, age-matched to the first group. They were 14 males and 9 females, 37-43 weeks' gestation, with birth weights from 2,250 to $4,800 \mathrm{~g}$, and aged 1 day to 8 months at the time of death (see Table 2).

\section{Histological processing}

Temporal bones were fixed between 1 and $17 \mathrm{~h}$ after death in neutral-buffered $(10 \%)$ formalin, decalcified with $5 \%$ trichloroacetic acid, and embedded in celloidin. The blocks were cut at $20 \mu \mathrm{m}$ in the horizontal plane; every tenth section was stained with hematoxylin-eosin, mounted on glass slides with Permount, and coverslipped. The cochlear spiral in each case was reconstructed in two dimensions (Schuknecht 1993), and the distance from the cochlear base of each section through the cochlear duct was computed.

\section{Histological analysis}

The condition of the cochlear duct was evaluated in every mounted section. The loss of inner and outer hair cells was quantified using an oil immersion $\times 100$ objective. Focusing through the entire thickness of each section, the fractional survival of inner and outer hair cells was estimated, even in tangential sections, by (1) determining the numbers of hair cells remaining in each row and then (2) estimating the number which should have been present by counting the numbers of outer and/or inner pillar cells. As seen in Figure 1, the presence of hair cells could be verified based on the coappearance of three key morphological markers: an appropriately positioned nucleus, a clear cuticular plate, and (usually) also a hair bundle. In addition, the condition of the supporting cells, stria vascularis, spiral ligament, Reissner's membrane, and the spiral ganglion were qualitatively evaluated in each section, and the presence of blood in the scalae was noted.

\section{RESULTS}

\section{Clinical profiles}

The clinical conditions reflected that of a standard NICU patient population (see Tables 1 and 2). In the preterm group, with gestation $\leq 36$ weeks, respiratory insufficiency was the most frequent clinical condition (21 patients) mostly because of hyaline membrane disease (ten patients), followed by septicemia (ten patients), neurological problems (seven patients), and hyperbilirubinemia/jaundice (six patients). In the full-term group, respiratory problems were also the most frequent clinical condition (20 patients), but mostly caused by meconium aspiration (14 patients), followed by sepsis (six patients), enterocolitis (three patients), and neurological problems (two cases).

\section{Postmortem autolysis}

As shown by the micrographs in Figure 1, the tissue preservation was excellent in many of our neonatal temporal bones, presumably because so many were harvested within a few hours of death. Nevertheless, postmortem autolysis is unavoidable in human material. To avoid confusing pre- and postmortem damage to the hair cells, we defined as postmortem autolysis any cases in which the reticular lamina was disrupted, with cellular debris floating in scala media, i.e., hair cell loss was considered as non-artifactual only if scar formation was 
TABLE 1

Summary of clinical findings for the preterm ears evaluated in this study, grouped by hair cell loss phenotype

\begin{tabular}{|c|c|c|c|c|c|c|c|c|}
\hline Case & Sex & $\begin{array}{l}\text { Gestation } \\
\text { (weeks) }\end{array}$ & $\begin{array}{l}\text { Age } \\
\text { (days) }\end{array}$ & $\begin{array}{l}\text { Birth } \\
\text { weight (g) }\end{array}$ & Postmortem (h) & Clinical conditions & $\begin{array}{l}\text { Hair cell } \\
\text { condition }\end{array}$ & $\begin{array}{l}\text { Blood in } \\
\text { scalae }\end{array}$ \\
\hline$\overline{I L}$ & $\mathrm{~F}$ & 26 & 23 & 900 & 7 & HMD, Septicemia, Metabolic issues & Normal & Yes \\
\hline IR & $\mathrm{F}$ & 26 & 23 & 900 & 7 & HMD, Septicemia, Metabolic issues & Normal & Yes \\
\hline $3 \mathrm{~L}$ & M & 26 & $<1$ & 1,480 & 7 & HMD, Umbilical hemorrhage & Normal & Yes \\
\hline $3 R$ & M & 26 & $<1$ & 1,480 & 7 & HMD, Umbilical hemorrhage & Normal & Yes \\
\hline $6 \mathrm{~L}$ & $\mathrm{~F}$ & 30 & $<1$ & 1,210 & 2 & $\begin{array}{l}\text { HMD, Pneumonia, Subependymal } \\
\text { hemorrhage, Otitis Media }\end{array}$ & Normal & \\
\hline $6 \mathrm{R}$ & $\mathrm{F}$ & 30 & $<1$ & 1,210 & 2 & $\begin{array}{l}\text { HMD, Pneumonia, Subependymal } \\
\text { hemorrhage, Otitis Media }\end{array}$ & Normal & \\
\hline $8 \mathrm{~L}$ & $\mathrm{~F}$ & 30 & $<1$ & 1,500 & $?$ & HMD, Pneumonia, Pneumothorax & Normal & \\
\hline $8 R$ & $\mathrm{~F}$ & 30 & $<1$ & 1,500 & $?$ & HMD, Pneumonia, Pneumothorax & Normal & \\
\hline $9 \mathrm{~L}$ & $\mathrm{~F}$ & 31 & 2 & 1,940 & 2 & $\begin{array}{l}\text { HMD, Pneumonia with } \\
\text { Klebsiela, Septicemia }\end{array}$ & Normal & \\
\hline $9 \mathrm{R}$ & $\mathrm{F}$ & 31 & 2 & 1,940 & 2 & $\begin{array}{l}\text { HMD, Pneumonia with } \\
\text { Klebsiela, Septicemia }\end{array}$ & Normal & \\
\hline $15 \mathrm{~L}$ & M & 32 & 1 & 1,820 & 13 & Respiratory Insufficiency & Normal & \\
\hline $15 R$ & M & 32 & 1 & 1,820 & 13 & Respiratory Insufficiency & Normal & \\
\hline $17 \mathrm{~L}$ & M & 33 & 16 & 1,960 & 11 & $\begin{array}{l}\text { Hyperbilirubinemia, Hydrocephaly, } \\
\text { Anemia, Septicemia, Toxoplasmosis }\end{array}$ & Normal & \\
\hline $19 \mathrm{~L}$ & M & 34 & 1 & 1,490 & ? & Hypoxia & Normal & \\
\hline $19 R$ & M & 34 & 1 & 1,490 & ? & Hypoxia & Normal & \\
\hline $20 \mathrm{~L}$ & M & 34 & 195 & 1,600 & 9 & Pneumonia, Convulsions, Diarrhea & Normal & \\
\hline $20 \mathrm{R}$ & M & 34 & 195 & 1,600 & 9 & Pneumonia, Convulsions, Diarrhea & Normal & \\
\hline $21 \mathrm{~L}$ & $\mathrm{~F}$ & 34 & 90 & 1,760 & 2 & Congenital cardiomyopathy & Normal & \\
\hline $21 R$ & $\mathrm{~F}$ & 34 & 90 & 1,760 & 2 & Congenital cardiomyopathy & Normal & \\
\hline $23 \mathrm{R}$ & M & 34 & 0 & 2,350 & 2 & Pneumothorax bilateral, Hypoxia & Normal & \\
\hline $27 \mathrm{~L}$ & M & 36 & 10 & 1,800 & 2 & $\begin{array}{l}\text { Hyperbilirubinemia, HMD, } \\
\text { Pulmonary hypertension }\end{array}$ & Normal & \\
\hline $27 R$ & M & 36 & 10 & 1,800 & 2 & $\begin{array}{l}\text { Hyperbilirubinemia, HMD, } \\
\text { Pulmonary hypertension }\end{array}$ & Normal & \\
\hline $16 \mathrm{~L}$ & $\mathrm{~F}$ & 33 & 31 & 1,170 & 2 & $\begin{array}{l}\text { Septicemia, Necrotizing enterocolitis, } \\
\text { Hydrocephaly, Convulsions }\end{array}$ & $\mathrm{OHC}$ loss & \\
\hline $4 \mathrm{~L}$ & M & 29 & 57 & 950 & $?$ & HMD, Septicemia, Renal insufficiency & $\mathrm{OHC}$ loss base & \\
\hline $4 \mathrm{R}$ & M & 29 & 57 & 950 & $?$ & HMD, Septicemia, Renal insufficiency & $\mathrm{OHC}$ loss base & \\
\hline $17 R$ & M & 33 & 16 & 1,960 & 11 & $\begin{array}{l}\text { Hyperbilirubinemia, Hydrocephaly, } \\
\text { Anemia, Septicemia, Toxoplasmosis }\end{array}$ & $\mathrm{OHC}$ loss base & \\
\hline $16 R$ & $\mathrm{~F}$ & 33 & 31 & 1,170 & 2 & $\begin{array}{l}\text { Septicemia, Necrotizing enterocolitis, } \\
\text { Hydrocephaly, Convulsions }\end{array}$ & $\begin{array}{l}\mathrm{IHC} \text { and } \\
\mathrm{OHC} \text { loss }\end{array}$ & \\
\hline $24 \mathrm{~L}$ & M & 34 & 28 & 2,750 & 1 & $\begin{array}{l}\text { Hyperbilirubinemia, Pneumothorax, } \\
\text { Meningitis, Septicemia, Pneumonia }\end{array}$ & $\begin{array}{l}\mathrm{IHC} \text { and basal } \\
\mathrm{OHC} \text { loss }\end{array}$ & \\
\hline $24 R$ & M & 34 & 28 & 2,750 & 1 & $\begin{array}{l}\text { Hyperbilirubinemia, Pneumothorax, } \\
\text { Meningitis, Septicemia, Pneumonia }\end{array}$ & $\begin{array}{l}\mathrm{IHC} \text { and basal } \\
\mathrm{OHC} \text { loss }\end{array}$ & \\
\hline $5 \mathrm{~L}$ & M & 30 & 24 & 1,200 & 10 & $\begin{array}{l}\text { Hyperbilirubinemia, HMD, Anemia, } \\
\text { Septicemia, Intracranial hemorrhage }\end{array}$ & IHC loss & Yes \\
\hline $5 R$ & M & 30 & 24 & 1,200 & 10 & $\begin{array}{l}\text { Hyperbilirubinemia, HMD, Anemia, } \\
\text { Septicemia, Intracranial hemorrhage }\end{array}$ & $\mathrm{IHC}$ loss & Yes \\
\hline $11 \mathrm{~L}$ & M & 31 & 12 & 1,600 & 1.5 & $\begin{array}{l}\text { Hyperbilirubinemia, HMD, Septicemia, } \\
\text { Necrotizing enterocolitis }\end{array}$ & IHC loss & \\
\hline $11 \mathrm{R}$ & $M$ & 31 & 12 & 1,600 & 1.5 & $\begin{array}{l}\text { Hyperbilirubinemia, HMD, Septicemia, } \\
\text { Necrotizing enterocolitis }\end{array}$ & IHC loss & \\
\hline $14 \mathrm{~L}$ & M & 32 & 19 & 1,300 & 15 & $\begin{array}{l}\text { HMD, Bronchial Dysplasia, } \\
\text { Hydrocephaly with hemorrhage }\end{array}$ & IHC loss & Yes \\
\hline $14 \mathrm{R}$ & $M$ & 32 & 19 & 1,300 & 15 & $\begin{array}{l}\text { HMD, Bronchial Dysplasia, } \\
\text { Hydrocephaly with hemorrhage }\end{array}$ & IHC loss & Yes \\
\hline $18 \mathrm{~L}$ & M & 33 & 12 & 2,120 & 17 & $\begin{array}{l}\text { Respiratory insufficiency, Meningitis, } \\
\text { Septicemia, VSD, Pneumonia }\end{array}$ & $\mathrm{IHC}$ loss & \\
\hline $18 \mathrm{R}$ & M & 33 & 12 & 2,120 & 17 & $\begin{array}{l}\text { Respiratory Insufficiency, Meningitis, } \\
\text { Septicemia, VSD, Pneumonia }\end{array}$ & IHC loss & \\
\hline
\end{tabular}

Ears with postmortem autolysis are not included. Age refers to the age at death; postmortem time refers to the elapsed time between death and temporal bone removal $H M D$ hyaline membrane disease $V S D$ ventricular septal defect 
TABLE 2

Summary of clinical findings for the full-term ears evaluated in this study, grouped by hair cell loss phenotype

\begin{tabular}{|c|c|c|c|c|c|c|c|c|}
\hline Case & Sex & $\begin{array}{l}\text { Gestation } \\
\text { (weeks) }\end{array}$ & $\begin{array}{l}\text { Age } \\
\text { (days) }\end{array}$ & $\begin{array}{l}\text { Birth } \\
\text { weight (g) }\end{array}$ & Postmortem (h) & Clinical conditions & $\begin{array}{l}\text { Hair cell } \\
\text { condition }\end{array}$ & $\begin{array}{l}\text { Blood in } \\
\text { scalae }\end{array}$ \\
\hline $28 \mathrm{~L}$ & $\mathrm{~F}$ & 37 & 7 & 2,820 & 4 & $\begin{array}{l}\text { Hepatic infarct, Hypoxia, } \\
\text { Convulsions, Pneumonia }\end{array}$ & Normal & \\
\hline $30 L$ & M & 38 & 48 & 3,760 & 2 & $\begin{array}{l}\text { Necrotizing enterocolitis, } \\
\text { Convulsions, Septicemia, Anemia }\end{array}$ & Normal & \\
\hline $30 R$ & M & 38 & 48 & 3,760 & 2 & $\begin{array}{l}\text { Necrotizing enterocolitis, } \\
\text { Convulsions, Septicemia, Anemia }\end{array}$ & Normal & \\
\hline $33 R$ & $\mathrm{~F}$ & 40 & 1 & 4,000 & 2 & Meconium aspiration & Normal & \\
\hline 34L & $\mathrm{F}$ & 40 & 1 & 2,400 & 2 & Meconium aspiration & Normal & Yes \\
\hline $34 \mathrm{R}$ & $\mathrm{F}$ & 40 & 1 & 2,400 & 2 & Meconium aspiration & Normal & Yes \\
\hline $35 \mathrm{~L}$ & M & 40 & 3 & 2,250 & 2 & $\begin{array}{l}\text { Pulmonary hemorrhage, } \\
\text { Respiratory insufficiency }\end{array}$ & Normal & \\
\hline $35 R$ & M & 40 & 3 & 2,250 & 2 & $\begin{array}{l}\text { Pulmonary Hemorrhage, } \\
\text { Respiratory insufficiency }\end{array}$ & Normal & \\
\hline $37 \mathrm{~L}$ & M & 40 & 8 & 2,850 & 6 & $\begin{array}{l}\text { Meconium aspiration, } \\
\text { Pneumothorax, Septicemia }\end{array}$ & Normal & Yes \\
\hline $37 R$ & M & 40 & 8 & 2,850 & 6 & $\begin{array}{l}\text { Meconium aspiration, } \\
\text { Pneumothorax, Septicemia }\end{array}$ & Normal & Yes \\
\hline $38 \mathrm{~L}$ & M & 40 & 11 & 3,200 & 13 & $\begin{array}{l}\text { Cyanosis, Respiratory insufficiency, } \\
\text { Aspiration }\end{array}$ & Normal & \\
\hline $38 \mathrm{R}$ & M & 40 & 11 & 3,200 & 13 & $\begin{array}{l}\text { Cyanosis, Respiratory insufficiency, } \\
\text { Aspiration }\end{array}$ & Normal & \\
\hline $39 L$ & $\mathrm{~F}$ & 40 & 240 & 3,020 & 3 & $\begin{array}{l}\text { Meconium Aspiration, Pneumonia, } \\
\text { convulsions, Hydrocephaly }\end{array}$ & Normal & \\
\hline $39 R$ & $\mathrm{~F}$ & 40 & 240 & 3,020 & 3 & $\begin{array}{l}\text { Meconium aspiration, Pneumonia, } \\
\text { Convulsions, Hydrocephaly }\end{array}$ & Normal & \\
\hline $41 \mathrm{R}$ & $\mathrm{F}$ & 41 & 1 & 2,550 & 2.5 & Meconium aspiration, Pneumothorax & Normal & \\
\hline $44 \mathrm{~L}$ & $\mathrm{~F}$ & 41 & 9 & 4,000 & 2.5 & Pneumonia with aspiration, Septicemia & Normal & \\
\hline $44 \mathrm{R}$ & $\mathrm{F}$ & 41 & 9 & 4,000 & 2.5 & Pneumonia with aspiration, Septicemia & Normal & \\
\hline $45 \mathrm{~L}$ & M & 42 & 1 & 3,175 & 5 & Meconium aspiration, Pneumothorax & Normal & \\
\hline $45 R$ & M & 42 & 1 & 3,175 & 5 & Meconium aspiration, Pneumothorax & Normal & \\
\hline $46 R$ & M & 42 & 1 & 3,300 & 1 & Meconium aspiration & Normal & Yes \\
\hline $48 \mathrm{~L}$ & M & 42 & 2 & 4,200 & 2 & $\begin{array}{l}\text { Meconium aspiration, } \\
\text { Hypoxia, Pneumothorax }\end{array}$ & Normal & \\
\hline $48 \mathrm{R}$ & M & 42 & 2 & 4,200 & 2 & $\begin{array}{l}\text { Meconium aspiration, } \\
\text { Hypoxia, Pneumothorax }\end{array}$ & Normal & \\
\hline $49 \mathrm{~L}$ & M & 42 & 4 & 3,480 & 3 & Meconium aspiration, Hypoxia & Normal & \\
\hline $49 R$ & M & 42 & 4 & 3,480 & 3 & Meconium aspiration, Hypoxia & Normal & \\
\hline $50 \mathrm{~L}$ & $\mathrm{~F}$ & 43 & 1 & 3,700 & $?$ & Meconium aspiration & Normal & \\
\hline $50 \mathrm{R}$ & $\mathrm{F}$ & 43 & 1 & 3,700 & $?$ & Meconium aspiration & Normal & \\
\hline $36 \mathrm{~L}$ & M & 40 & 8 & 2,645 & 2 & Hypoxia, Convulsions, Septicemia & $\mathrm{OHC}$ loss & \\
\hline $36 \mathrm{R}$ & M & 40 & 8 & 2,645 & 2 & Hypoxia, Convulsions, septicemia & $\mathrm{OHC}$ loss & \\
\hline $32 \mathrm{~L}$ & $\mathrm{~F}$ & 39 & 18 & 2,480 & 1 & $\begin{array}{l}\text { Necrotizing enterocolitis, } \\
\text { Convulsions, Septicemia }\end{array}$ & $\mathrm{OHC}$ loss & \\
\hline $32 \mathrm{R}$ & $\mathrm{F}$ & 39 & 18 & 2,480 & 1 & $\begin{array}{l}\text { Necrotizing enterocolitis, } \\
\text { Convulsions, Septicemia }\end{array}$ & $\mathrm{OHC}$ loss & \\
\hline $29 L$ & M & 38 & 12 & 3,440 & 7 & $\begin{array}{l}\text { Accidental ligature of pulmonary artery, } \\
\text { Pulmonary infarct, Pneumonia }\end{array}$ & $\mathrm{OHC}$ loss base & Yes \\
\hline $29 R$ & M & 38 & 12 & 3,440 & 7 & $\begin{array}{l}\text { Accidental ligature of pulmonary artery, } \\
\text { Pulmonary infarct, Pneumonia }\end{array}$ & $\mathrm{OHC}$ loss base & Yes \\
\hline $42 \mathrm{~L}$ & M & 41 & 2 & 3,200 & 3 & $\begin{array}{l}\text { Meconium Aspiration, Hypoxia, } \\
\text { HIC, Septicemia }\end{array}$ & $\begin{array}{l}\mathrm{IHC} \text { and } \\
\mathrm{OHC} \text { loss }\end{array}$ & Yes \\
\hline $42 \mathrm{R}$ & M & 41 & 2 & 3,200 & 3 & $\begin{array}{l}\text { Meconium aspiration, Hypoxia, } \\
\text { HIC, Septicemia }\end{array}$ & $\begin{array}{l}\text { IHC and } \\
\mathrm{OHC} \text { loss }\end{array}$ & Yes \\
\hline $46 \mathrm{~L}$ & M & 42 & 1 & 3,300 & 1 & Meconium aspiration & $\begin{array}{l}\mathrm{IHC} \text { and } \\
\mathrm{OHC} \text { loss }\end{array}$ & \\
\hline $33 \mathrm{~L}$ & $\mathrm{~F}$ & 40 & 1 & 4,000 & 2 & Meconium aspiration & IHC loss & Yes \\
\hline
\end{tabular}

Ears with postmortem autolysis are not included. Age refers to the age at death; postmortem time refers to the elapsed time between death and temporal bone removal 

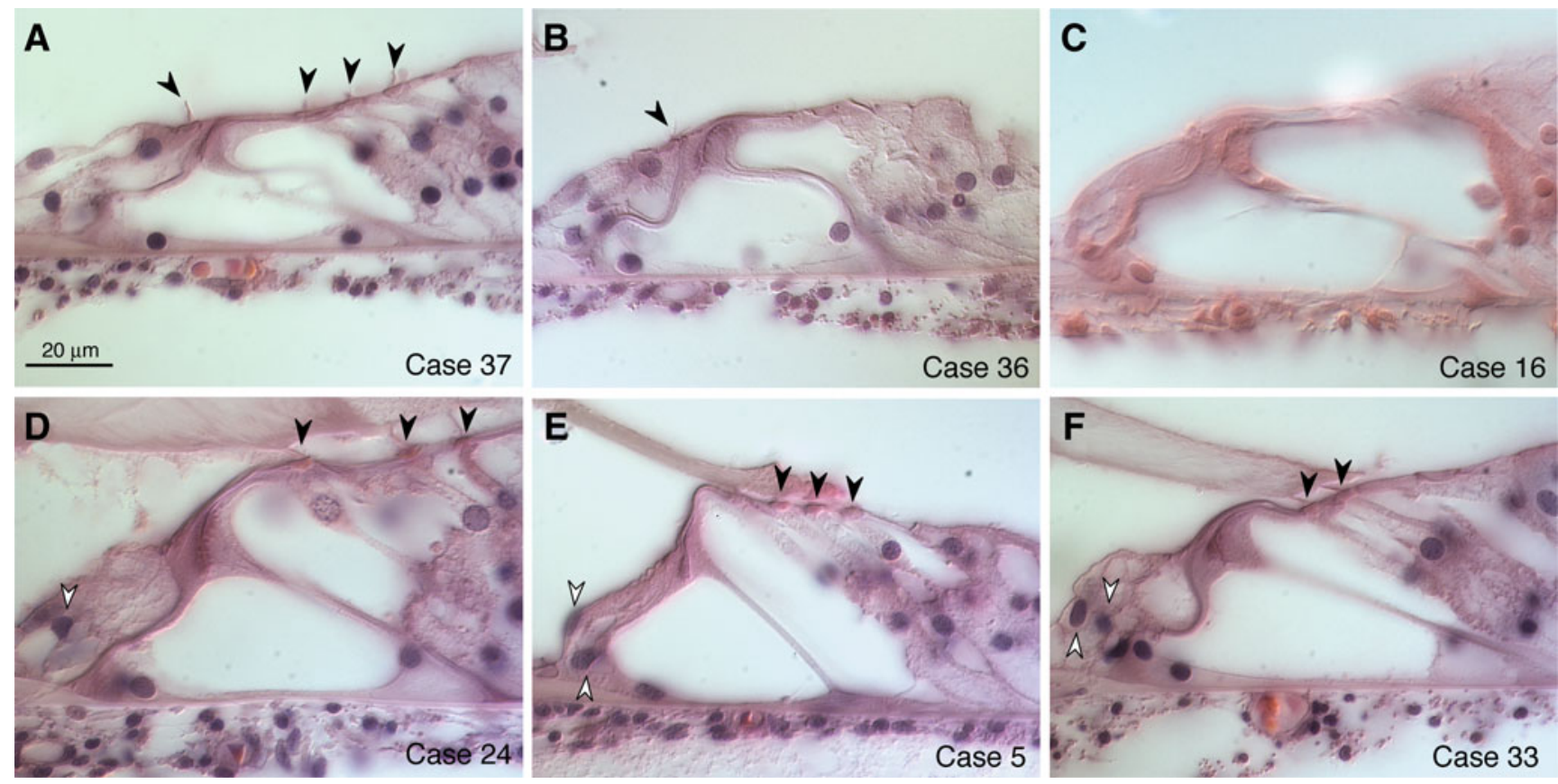

FIG. 1. Tissue preservation was adequate in most cases to allow identification of inner and outer hair cells based on the combined presence or absence of nuclei, cuticular plates, and hair bundles. Filled arrowheads point to remaining hair bundles and cuticular

plates; open arrowheads point to nuclei of remaining supporting cells in the IHC area. Note that the reticular lamina is intact in regions of hair cells loss. A Normal ear; B selective OHC loss; C combined IHC and $\mathrm{OHC}$ loss; $\mathbf{D}-\mathbf{F}$ complete IHC loss with scattered or no OHC loss.

complete, at least as far as can be judged at the light microscopic level. By these criteria, 27 ears (17 preterm and 10 term) had to be eliminated due to the presence of autolytic changes throughout much (11 ears) or all (16 ears) of the cochlear spiral. For the 11 cases with subtotal involvement (usually restricted to the basal half of the cochlea), the remainder of the cochlea appeared normal.

\section{Qualitative analysis}

Within the organ of Corti, significant loss of hair cells was commonly seen in both full-term and preterm infants. In the full-term infants, that loss was typically

seen as selective loss of outer hair cells (e.g., Figure 1B) or combined loss of inner and outer hair cells (e.g., Figure 1C). In the preterm cases (e.g. Figure 1D-F), there was a surprising number of cases with selective loss of inner hair cells: ten ears from five infants. When selective inner hair cell (IHC) loss was seen, the supporting cells in the IHC area appeared to be intact (Figure 1D-F), and both inner and outer pillar cells appeared normal and present in normal numbers.

Qualitative analysis of the spiral ganglion suggested no loss of neurons, even in the cases of widespread IHC loss, as can be seen from the micrographs in Figure 2 comparing a normal ear to one with selective

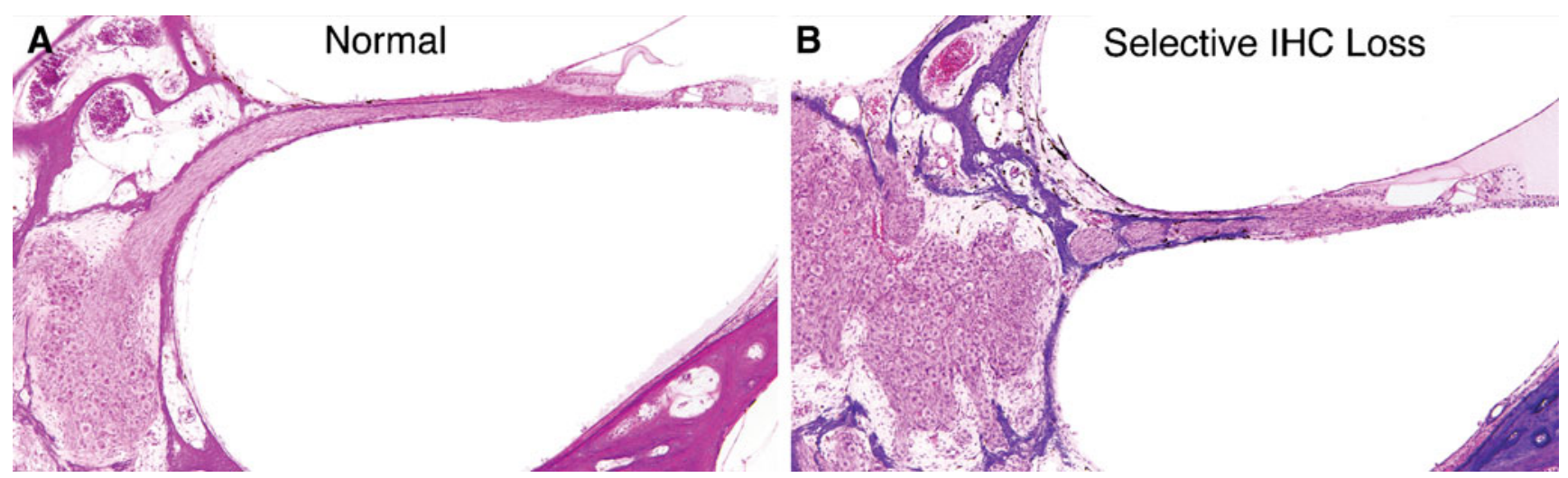

FIG. 2. Spiral ganglion region in a normal ear (A) (case 37) and in a preterm case with massive IHC loss throughout the cochlea (B) (case 24). There is no significant loss of spiral ganglion cells despite the IHC loss. 
IHC loss. Neuronal loss was also not visible among the peripheral axons of cochlear nerve fibers in the osseous spiral lamina.

There was a significant amount of blood in the cochlear scalae in a subset of cases: eight ears from four preterm infants and ten ears from six full-term infants (see Tables 1 and 2, respectively). There was little clearcut pathology in any of the accessory structures of the cochlear duct, i.e., stria vascularis, spiral ligament, spiral limbus, and Reissner's or tectorial membranes.

\section{Hair cell counts}

Of the preterm and full-term ears that passed the postmortem autolysis screen, 22 of $37(59 \%)$ and 26 of $36(72 \%)$, respectively, were classified as normal, i.e., showed no more than two consecutive slides with any hair cell loss in any of the four rows. As shown in Figure 1 (top row), these scattered islands of hair cell loss were seen throughout the cochlear spiral.

Selective loss of outer hair cells was seen in 4 of 37 (11\%) of preterm and 6 of $36(17 \%)$ of full-term ears. As can be seen by the symbol types in Figure 3 (middle row), this condition was typically bilateral: one preterm case (circles) and all three full-term cases (circles, triangles, and squares) were bilateral. The cytocochleograms also show that selective outer hair cell (OHC) loss was usually present in the basal half of the cochlea.

\section{Pre-Term Cases}
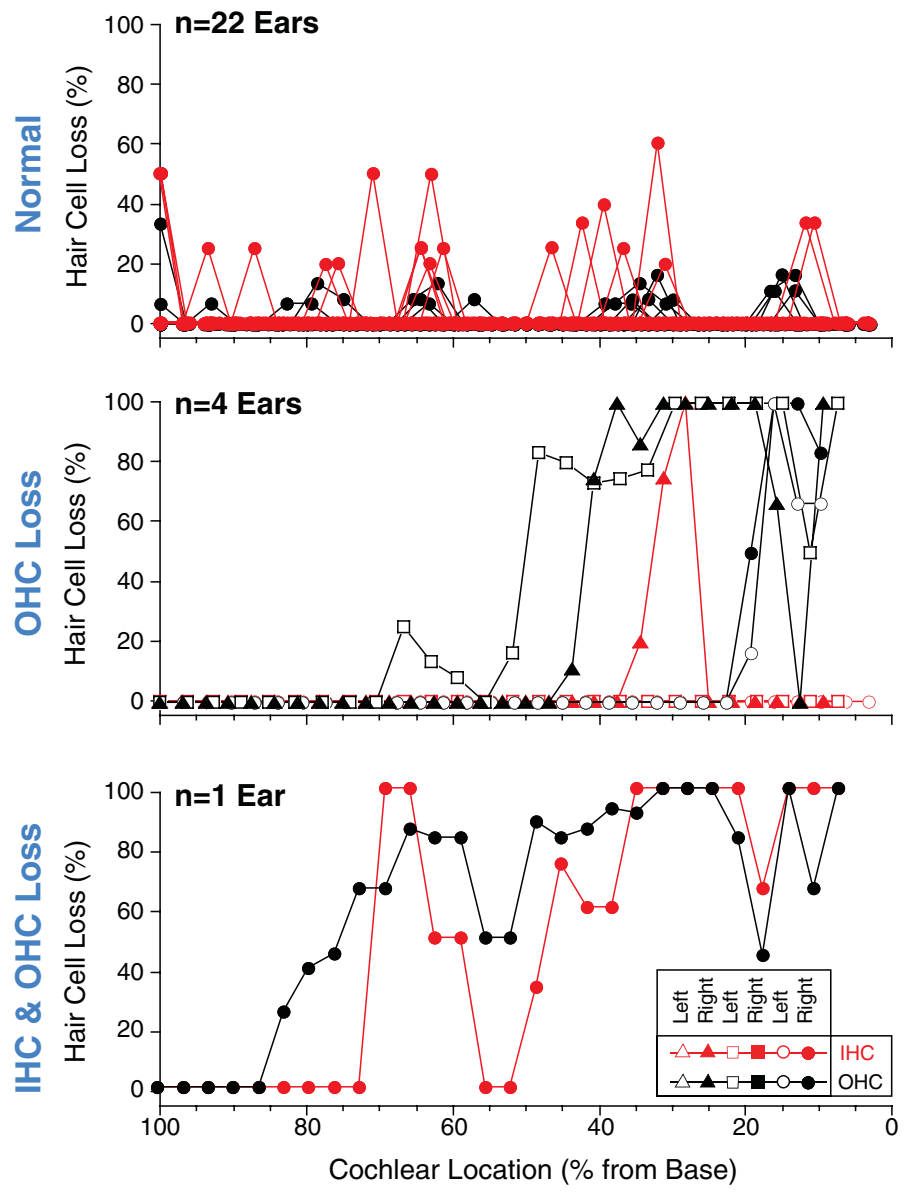

FIG. 3. Cytocochleograms showing patterns of inner and outer hair cell loss for all ears in this study, except (1) those with postmortem autolysis and (2) those with selective inner hair cell loss (which are shown in Figures 4 and 5). As seen in the top row, 22 of 37 preterm ears and 26 of 36 full-term ears were "normal," i.e., showed minimal hair cell loss. As shown in the middle row, 4 of 37 preterm and 6 of 36 fullterm ears showed OHC loss: such loss was usually in the basal half of the cochlea and usually symmetrical between the two ears of one individual. As shown in the bottom row, combined (and co-extensive)

\section{Full-Term Cases}
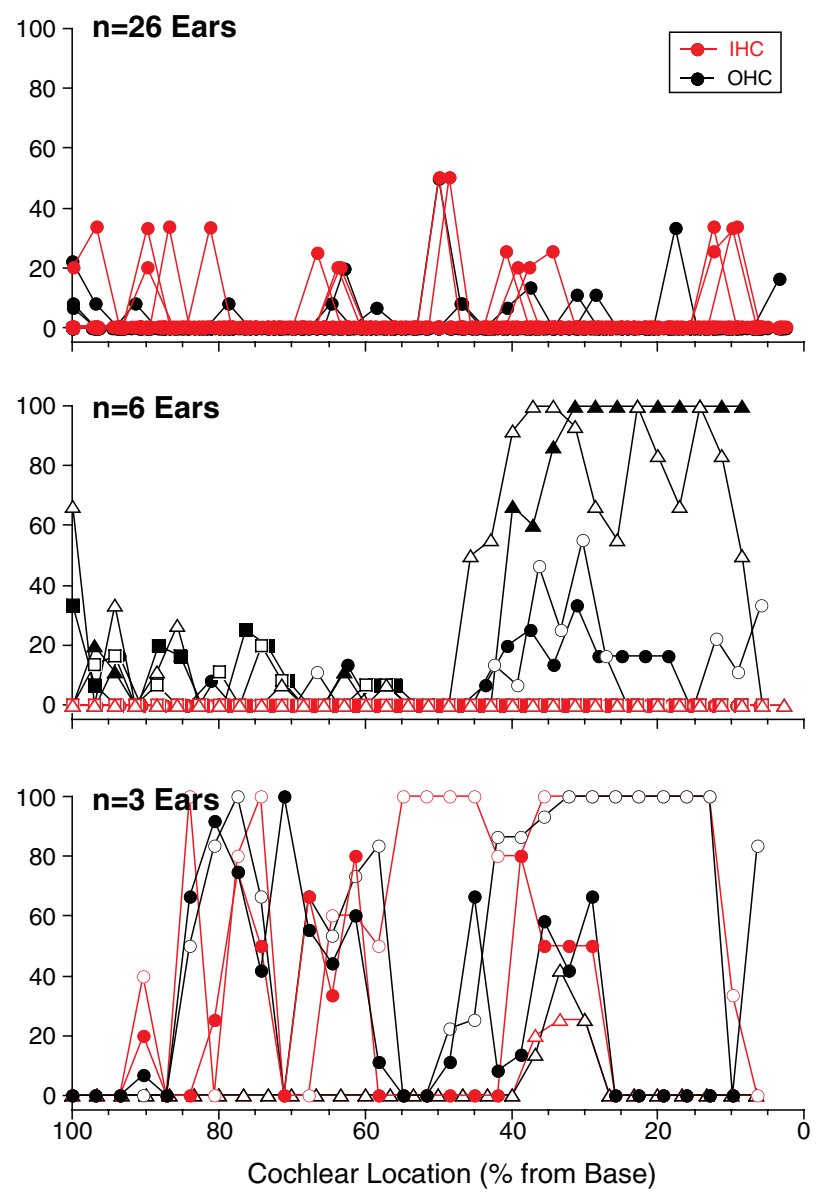

IHC/OHC loss was seen in 1 of 37 pre-term and 3 of 36 full-term ears: this damage was bilaterally symmetrical in only one case. Key at lower left applies to the bottom two rows, where different symbols are used to allow identification of right and left ears from the same case. Key at upper right applies to the top row, where no distinction is made between the right and left ears and where most of the data points for both $\mathrm{IHC}$ and $\mathrm{OHC}$ loss are clustered along the zero line (black points are hidden by red points). Values for $\mathrm{OHC}$ loss represent the average for all three rows. 
Combined and co-extensive loss of IHCs and OHCs was seen in 1 of 37 pre-term ears and 3 of 36 full-term ears. As seen in Figure 3 (bottom row), the damage was seen throughout the cochlear spiral in many of these cases. In only one ear (unfilled triangles in the full-term column) was the damage restricted to a relatively small island in the basal turn.

Large regions of selective IHC loss were seen in 10 of $37(27 \%)$ preterm ears and only 1 of $36(3 \%)$ fullterm ear (Figures 4 and 5, respectively). As seen in Figure 4, eight of ten of these preterm ears showed essentially no OHC loss, while a pair showed IHC loss throughout the cochlea spiral coupled with OHC loss in the basal half of the cochlea (case 24, top row). Also clear from Figure 4 is the observation that the IHC loss patterns tended to be symmetrical between the two ears and to be present throughout the cochlear spiral. The selective IHC loss in the one full-term case (Figure 5) was less significant, less symmetrical between the two ears, and less extensive in its spread along the cochlear spiral.

\section{DISCUSSION}

The known causes of selective IHC loss

The most salient findings of the present study were twofold: (1) that a high percentage of ears in both preterm $(41 \%)$ and full-term $(28 \%)$ populations show significant hair cell loss and (2) that a remarkably high percentage of preterm ears $(27 \%)$ show the relatively rare cochlear histopathology of selective loss of IHCs. The high percentage of ears with hair cell loss of all types is perhaps not surprising given that sensorineural hearing loss is significantly more common in NICU survivors than in babies not requiring such intense hospital care at birth (Xoinis et al. 2007) and that the ears analyzed here were from the population that was so seriously ill that they did not survive the NICU stay. Although many of these infants with various forms of sepsis may have been treated with aminoglycosides, such treatment is not highly correlated with hearing loss in NICU survivors (Hess et al. 1998).

The high percentage of preterm ears with selective IHC loss is surprising because in virtually every study of cochlear histopathology, whether from animal models or human temporal bones, and whether from acquired or genetic forms of sensorineural hearing loss, the OHCs are clearly more prone to degenerate and disappear from the inner ear than the IHCs (Schuknecht 1993). We are not aware of any report in the human temporal bone literature from adult ears of a case of selective IHC loss. There are two other reports of selective inner hair cell loss in neonatal human ears: one describes inner hair cell degeneration in one cochlea from a group of five preterm infants (Slack et al. 1986) and another, by
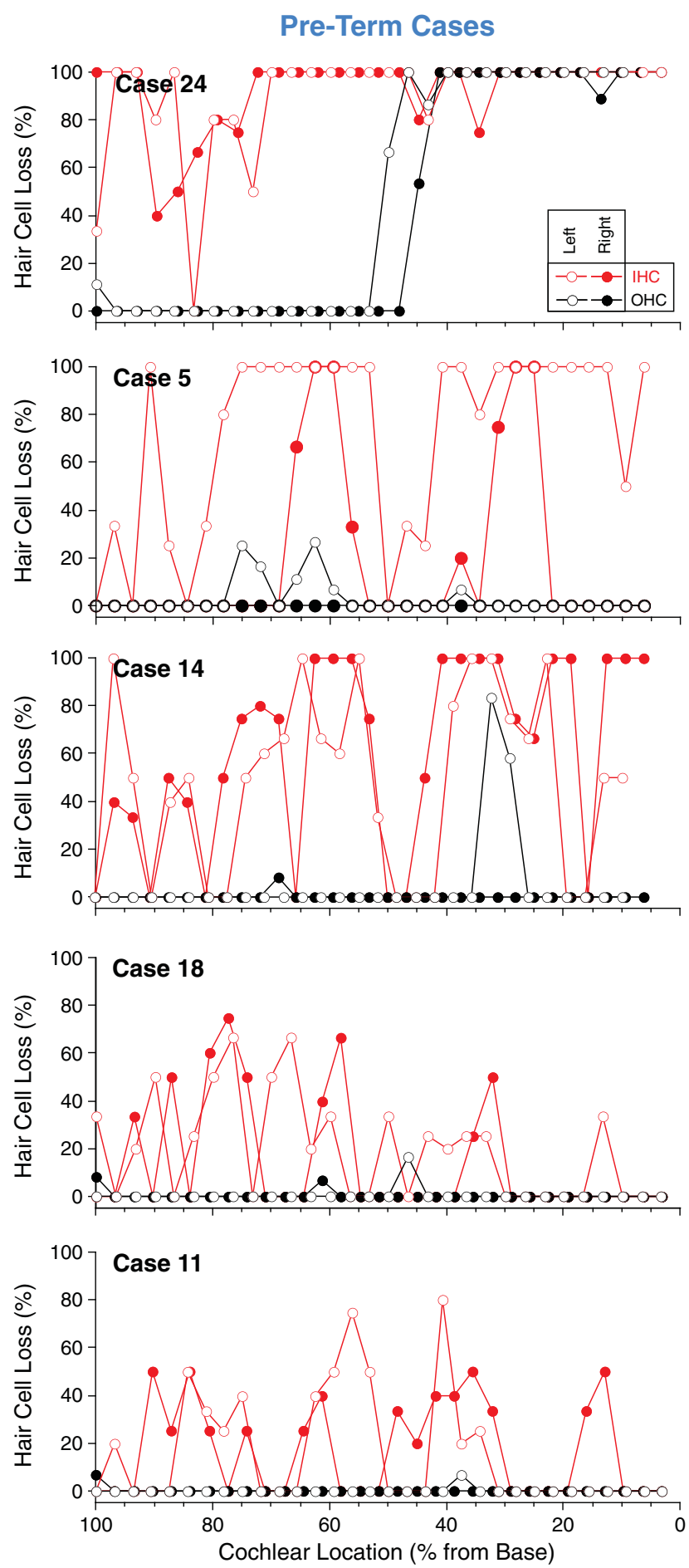

FIG. 4. Selective IHC loss was seen bilaterally in five preterm cases (ten ears). In each of the preterm cases, the degree and pattern of loss was similar in the two ears. In four of the pre-term cases (eight ears), the $\mathrm{OHC}$ loss was minimal; in one case (two ears), there was $\mathrm{OHC}$ and IHC loss in the basal half of the cochlear combined with selective IHC loss in the apical half (case 24).

our group, reports on a smaller subset of the larger set of bones examined here (Amatuzzi et al. 2001).

In the animal literature, there are three models of selective IHC loss: the carboplatin-treated chinchilla 


\section{Full-Term Case}

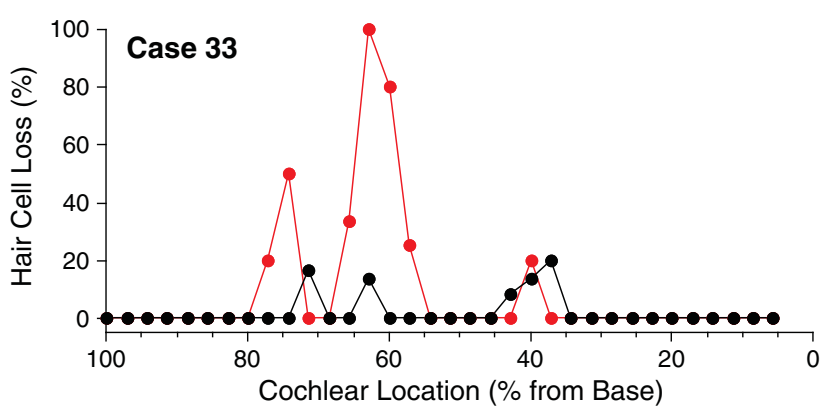

FIG. 5. In the only full-term ear with selective IHC loss (case 33), the degree and extent of the loss was smaller than in any of the preterm cases.

(Takeno et al. 1994; Wake et al. 1994), a mutant mouse with targeted deletion of thiamine transporter gene (Liberman et al. 2006), and the Bronx Waltzer mouse (Schrott et al. 1989), harboring a spontaneous mutation in an as-yet-unidentified gene. The carboplatin model is curious because administration of the same chemotherapeutic drug to other mammals, e.g., the guinea pig (Taudy et al. 1992), results in the more common pattern of ototoxic drug-induced damage, i.e., loss of both OHCs and IHCs, with the OHC loss extending further toward the cochlear apex. In carboplatin-treated chinchillas, the IHC loss begins in the upper basal turn, then spreads apically and basally as the dosage increases (Liberman et al. 1997). In the mutant mouse lacking a high-affinity thiamine transporter expressed selectively in IHCs, the cell degeneration begins in the apical half of the cochlea and spreads basally as the thiamine deficiency becomes more severe (Liberman et al. 2006). A possible link between carboplatin effects and thiamine transporter effects has been suggested (Liberman et al. 2006): the sulfurcontaining antioxidant methionine decreases the ototoxicity of platinum compounds such as carboplatin, by the formation of sulfur-platinum adducts. Carboplatin may be ototoxic to inner hair cells because it binds to thiamine, which also contains sulfur, and leads to problems selective to IHCs in those species where the high-affinity thiamine transporter is expressed only in the IHCs, e.g., mouse and possibly chinchilla (Liberman et al. 2006). If true, it is possible that this thiamine transporter is not yet fully expressed in premature IHCs, thereby leading to the selective IHC death observed here in cases of extreme systemic stress.

Selective IHC loss, prematurity, and auditory neuropathy

The clinical condition known as AN, defined as a hearing impairment seen with absent ABRs despite present OAEs (Starr et al. 1996), clearly has several underlying etiologies, including both genetic and acquired. The maintenance of OAEs indicates (1) that the middle ear must be normal or near normal and (2) that basic cochlear architecture must be intact, including the stria vascularis, to produce an endolymphatic potential and the OHCs to drive the cochlear amplifier (Shera 2004). Since 95\% of the sensory fibers of the cochlear nerve, and all of the myelinated afferent population, contact only IHCs (Liberman 1982) and since even complete loss of IHCs does not affect OAE production (Liberman et al. 1997), AN could theoretically arise from either (1) loss of IHCs, (2) interruption of synaptic transmission between IHCs and their sensory innervation, or (3) degeneration of the sensory neurons themselves.

It has been recently argued that selective IHC loss, as seen in carboplatin-treated chinchillas, is insufficient to account for the loss of neural potentials in AN patients (El-Badry and McFadden 2009). However, the argument's validity depends on the degree of IHC loss. It is true that the spread of excitation along the cochlear spiral with increasing level of an ABR test tone, for example, insures that a diffuse moderate loss of cochlear neurons, e.g., $75 \%$, can be compensated for with a relatively modest increase in stimulus SPL. However, as the IHC loss exceeds $80-90 \%$, as is seen in at least four of the premature infant ears in the present study (Figure 4), the remaining ABR waves will disappear (Liberman et al. 1997), especially if the only remaining fibers are in the apical turn, where response latencies are not well synchronized (Antoli-Candela and Kiang 1978) due to the progressive slowing of the mechanical traveling wave.

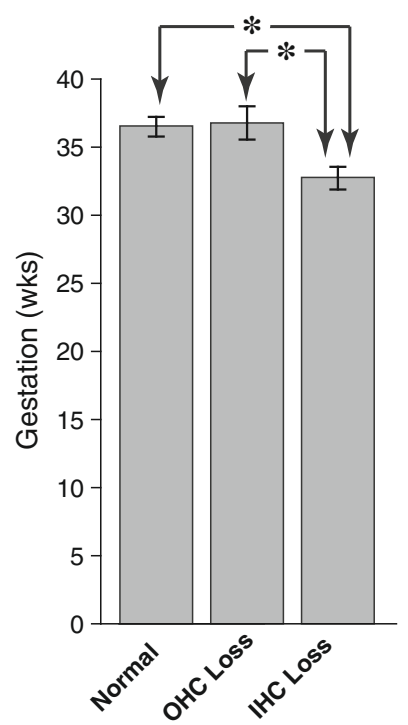

FIG. 6. Mean gestation time in cases with selective inner hair cell loss was significantly less than that seen in normal ears and in ears with $\mathrm{OHC}$ or combined $\mathrm{OHC}$ and IHC loss. Stars indicate statistical significance at the $p<0.05$ level by unpaired $t$ test. Error bars show SEMs. 
It is also commonly suggested that AN could arise from dys-synchrony in the sound-evoked responses of the cochlear nerve (Starr et al. 1991). Although, theoretically, a demyelinating disorder could produce such a phenotype, there are no animal models of either genetic or acquired cochlear disorders in which true cochlear nerve dys-synchrony has been demonstrated, i.e., in which the response latencies of cochlear nerve populations are so jumbled that no coherent peak emerges in the gross potential. However, there is at least one type of synaptic dysfunction, i.e., loss of presynaptic ribbons (Buran et al. 2010), which reduces the reliability with which spikes are elicited at stimulus onset, the net effect of which is to greatly reduce the size of the ABR potentials in affected animals.

The known genetic causes of AN include synaptic dysfunction and cochlear nerve degeneration, but not selective IHC loss. Mutations in otoferlin, a gene expressed in the IHCs and involved in calcium-activated vesicle release at the afferent synapse (Beurg et al. 2010), lead to a type of AN in affected individuals (Santarelli et al. 2009). In the mouse model with targeted deletion of the otoferlin gene, the IHCs survive (Dulon et al. 2009). Mutations in two genes encoding mitochondrial proteins cause genetic hearing loss of the AN type in Mohr-Tranebjaerg syndrome (Bahmad et al. 2007) and Friedrich's ataxia (Lopez-Diaz-de-Leon et al. 2003), both of which are associated with massive degeneration of cochlear nerve fibers (Spoendlin 1974; Bahmad et al. 2007).

The causes of acquired AN are more poorly understood because there are few relevant temporal bone studies (Slack et al. 1986; Amatuzzi et al. 2001). Retrospective clinical studies have suggested that low birth weight and prematurity are risk factors for AN (Madden et al. 2002; Beutner et al. 2007; Xoinis et al. 2007; Teagle et al. 2010). Of course, prematurity is associated with a long list of comorbid factors including hyperbilirubinemia, hypoxia, necrotizing enterocolitis, bronchopulmonary dysplasia (Beutner et al. 2007; Teagle et al. 2010), and other clinical conditions also noted in the NICU charts of the premature infants in this study (Tables 1 and 2). Nevertheless, the frequency with which prematurity is associated with AN in the clinical literature is striking in light of the present results showing that the mean gestation period of infants with selective IHC loss was 32 weeks (Figure 6) compared with 36 weeks for those with normal ears and 36 weeks for those with more common histopathological patterns of OHC loss or combined OHC and IHC loss. These differences between the selective IHC loss group and both other groups were statistically significant $(p<$ 0.05 by unpaired $t$ test). These data mirror those of a recent clinical study finding that infants with AN showed, on average, 4-week shorter gestation periods than those with other forms of sensorineural hearing loss (Xoinis et al. 2007).

The long-term survival of cochlear nerve fibers following selective IHC loss should be important to the efficacy of cochlear implants as a treatment for this type of AN. Although we saw no signs of neural loss in the present study, the longest postnatal survival in an ear with selective IHC loss was only 1 month (see Table 1). The continued presence of supporting cells in the IHC area (Figure 1D-F) is important in this regard, given recent evidence that these supporting cells are a key source of the neurotrophins required for survival of spiral ganglion cells (Stankovic et al. 2004; Sugawara et al. 2005). If the supporting cellsupplied neurotrophins are sufficient to promote long-term neuronal survival in the absence of IHCs, patients with an AN associated with prematurity might benefit more from cochlear implants than those with AN arising from primary neural degeneration.

\section{ACKNOWLEDGMENTS}

This work was supported by NIH Grants: R01 DC0188 (MCL and P30 DC5029 (MCL) and from a grant from the Temporal Bone Foundation. We are grateful to Prof. Jorge Pizza from the Pathology Department of the Hospital de Niños in San Jose, Costa Rica, for granting access to obtain material for this research.

\section{REFERENCES}

Amatuzzi MG, Northrop C, Liberman MC, Thornton A, Halpin C, Herrmann B, Pinto Le, Saenz A, Carranza A, Eavey RD (2001) Selective inner hair cell loss in premature infants and cochlea pathological patterns from neonatal intensive care unit autopsies. Arch Otolaryngol Head Neck Surg 127:629-636

Antoli-Candela F Jr, Kiang NYS (1978) Unit activity underlying the N1 potential. In: Naunton RF, Fernández C (eds) Evoked electrical activity in the auditory nervous system. Academic, New York, pp 165-191

Bahmad F Jr, Merchant SN, Nadol JB Jr, Tranebjaerg L (2007) Otopathology in Mohr-Tranebjaerg syndrome. Laryngoscope 117:1202-1208

Beurg M, Michalski N, Safieddine S, Bouleau Y, Schneggenburger R, Chapman ER, Petit C, Dulon D (2010) Control of exocytosis by synaptotagmins and otoferlin in auditory hair cells. J Neurosci 30:13281-13290

Beutner D, Foerst A, Lang-Roth R, von Wedel H, Walger M (2007) Risk factors for auditory neuropathy/auditory synaptopathy. ORL J Otorhinolaryngol Relat Spec 69:239-244

Buran BN, Strenzke N, Neef A, Gundelfinger ED, Moser T, Liberman MC (2010) Onset coding is degraded in auditory nerve fibers from mutant mice lacking synaptic ribbons. J Neurosci 30:7587-7597

Cristobal R, Oghalai JS (2008) Hearing loss in children with very low birth weight: current review of epidemiology and pathophysiology. Arch Dis Child Fetal Neonatal Ed 93:F462-F468

D'Agostino JA, Austin L (2004) Auditory neuropathy: a potentially under-recognized neonatal intensive care unit sequela. Adv Neonatal Care 4:344-353 
Dulon D, Safieddine S, Jones SM, Petit C (2009) Otoferlin is critical for a highly sensitive and linear calcium-dependent exocytosis at vestibular hair cell ribbon synapses. J Neurosci 29:10474-10487

EL-BAdRy MM, McFadden SL (2009) Evaluation of inner hair cell and nerve fiber loss as sufficient pathologies underlying auditory neuropathy. Hear Res 255:84-90

Hess M, Finckh-Kramer U, Bartsch M, Kewitz G, Versmold H, Gross M (1998) Hearing screening in at-risk neonate cohort. Int J Pediatr Otorhinolaryngol 46:81-89

Liberman MC (1982) Single-neuron labeling in the cat auditory nerve. Science 216:1239-1241

Liberman MC, Chesney CP, Kujawa SG (1997) Effects of selective inner hair cell loss on DPOAE and CAP in carboplatin-treated chinchillas. Aud Neurosci 3:255-268

Liberman MC, Tartaglini E, Fleming JC, Neufeld EJ (2006) Deletion of SLC19A2, the high affinity thiamine transporter, causes selective inner hair cell loss and an auditory neuropathy phenotype. J Assoc Res Otolaryngol 7:211-217

Lopez-Diaz-de-Leon E, Silva-Rojas A, Ysunza A, Amavisca R, Rivera R (2003) Auditory neuropathy in Friedreich ataxia. A report of two cases. Int J Pediatr Otorhinolaryngol 67:641-648

Madden C, Rutter M, Hilbert L, Greinwald JH Jr, Choo DI (2002) Clinical and audiological features in auditory neuropathy. Arch Otolaryngol Head Neck Surg 128:1026-1030

Rance G, Beer DE, Cone-Wesson B, Shepherd RK, Dowell RC, King AM, Rickards FW, CLark GM (1999) Clinical findings for a group of infants and young children with auditory neuropathy. Ear Hear 20:238-252

Robertson CM, Howarth TM, Bork DL, Dinu IA (2009) Permanent bilateral sensory and neural hearing loss of children after neonatal intensive care because of extreme prematurity: a thirty-year study. Pediatrics 123:e797-e807

Santarelli R, Del Castillo I, Rodriguez-Ballesteros M, Scimemi P, Cama E, Arslan E, Starr A (2009) Abnormal cochlear potentials from deaf patients with mutations in the otoferlin gene. J Assoc Res Otolaryngol 10:545-556

Schrott A, Stephan K, Spoendlin H (1989) Hearing with selective inner hair cell loss. Hear Res 40:213-219

Schuknecht HF (1993) Pathology of the ear, 2nd edn. Lea \& Febiger, Baltimore
SHERA CA (2004) Mechanisms of mammalian otoacoustic emission and their implications for the clinical utility of otoacoustic emissions. Ear Hear 25:86-97

Slack RW, Wright A, Michaels L, Frohlich SA (1986) Inner hair cell loss and intracochlear clot in the preterm infant. Clin Otolaryngol Allied Sci 11:443-446

SpoEndLin HH (1972) Innervation densities of the cochlea. Acta Otolaryng 73:235-248

Spoendurn H (1974) Optic cochleovestibular degenerations in hereditary ataxias. II. Temporal bone pathology in two cases of Friedreich's ataxia with vestibulo-cochlear disorders. Brain 97:41-48

Stankovic K, Rio C, Xia A, Sugahara M, Adams JC, Liberman MC, CoRfas G (2004) Survival of adult spiral ganglion neurons requires erbB receptor signaling in the inner ear. J Neurosci 24:8651-8661

Starr A, McPherson D, Patterson J, Don M, Luxford W, Shannon R, Sininger Y, TonakaWa L, Waring M (1991) Absence of both auditory evoked potentials and auditory percepts dependent on timing cues. Brain 114(Pt 3):1157-1180

Starr A, Picton TW, Sininger Y, Hood LJ, Berlin CI (1996) Auditory neuropathy. Brain 119(Pt 3):741-753

Starr A, Sininger YS, Pratt H (2000) The varieties of auditory neuropathy. J Basic Clin Physiol Pharmacol 11:215-230

Sugawara M, Corfas G, Liberman MC (2005) Influence of supporting cells on neuronal degeneration after hair cell loss. J Assoc Res Otolaryngol 6:136-147

Takeno S, Harrison RV, Ibrahim D, Wake M, Mount RJ (1994) Cochlear function after selective inner hair cell degeneration induced by carboplatin. Hear Res 75:93-102

Taudy M, Syka J, Popelar J, Ulehlova L (1992) Carboplatin and cisplatin ototoxicity in guinea pigs. Audiology 31:293-299

Teagle HF, Roush Pa, Woodard JS, Hatch DR, Zdanski CJ, Buss E, Buchman CA (2010) Cochlear implantation in children with auditory neuropathy spectrum disorder. Ear Hear 31:325-335

Wake M, Takeno S, Ibrahim D, Harrison R (1994) Selective inner hair cell ototoxicity induced by carboplatin. Laryngoscope 104:488493

Xoinis K, Weirather Y, Mavoori H, Shaha SH, Iwamoto LM (2007) Extremely low birth weight infants are at high risk for auditory neuropathy. J Perinatol 27:718-723 